\title{
APPROAGHES REGARDING THE MANAGEMENT OF FOOD POLICIES IN THE CONTEXT OF THE AFRICAN SWINE FEUER GRISIS BASED ON A FOOD SUSTAINABILITY STATISTICAL MODEL
}

\author{
Valentin Marian Antohi ${ }^{1}$, Monica Laura Zlati ${ }^{2}$, Roxana Sârbu ${ }^{3}$, \\ Silvius Stanciu ${ }^{4 *}$,Florina Oana Virlănuță ${ }^{5}$ and Sorin Anagnoste ${ }^{6}$ \\ 1, 4, 5) Dunărea de Jos University, Galați, Romania \\ ${ }^{2)}$ Stefan cel Mare University, Suceava, Romania \\ ${ }^{3,6)}$ The Bucharest University of Economic Studies, Romania
}

Please cite this article as:

Antohi, V.M., Zlati, M.L., Sârbu, R., Stanciu, S., Virlănuță F.O. and Anagnoste, S., 2019. Approaches regarding the Management of Food Policies in the Context of the African Swine Fever Crisis based on a Food Sustainability Statistical Model. Amfiteatru Economic, 21(51), pp. 329-346.

\section{Article History}

Received: 30 December 2018

Revised: 15 February 2019

Accepted: 30 March 2019

DOI: $10.24818 / \mathrm{EA} / 2019 / 51 / 329$

\begin{abstract}
Food policies are focused on ensuring the consumption needs of the existing population in a given territory. In general, food policies are built on food continuity and production based on a pool of natural resources available at a given time. Critical food security incidents, particularly the epidemiological crises in livestock farming from a geographical area can significantly affect the population's food resources and disrupt applicable local and national food policies. Thus in some cases it is necessary to adopt food security plans and biosecurity procedures in order to isolate outbreaks, and limit the spread of the epidemic, protect the unaffected food and mitigate the negative impact of the crisis on the local sources of agro food production.

The main objective of the study was the analysis of food policies in Romania in the context of the recent outbreak of African swine fever epidemic. Based on bibliographic documentation and processing of official information on the effects of the epidemic on swine farms, the authors have proposed a food sustainability statistical model with practical applicability in assessing and quantifying the effects of African swine fever crisis in Romania. The results of the study showed the possibility of statistical modelling of the national food security indicators in the event of critical incidents in the agro-food chain. The model implementation simulation highlighted potential beneficial economic effects by modifying Romania's food policies.

The research results are new at national level, with a potential positive impact on scientific research in the field of economic and agro-food production. The designed statistical model may be useful to economic operators and, in particular, to national authorities in order to adjust food policies in critical food security situations, to limit the phenomena of destabilizing the consumer market and to avoid possible economic disruptions due to crisis situations in the livestock production sector.
\end{abstract}

Key words: food policies, African swine fever, pig farms, food sustainability statistical model, economic effects

Classification JEL: Q18, E21

*Corresponding author, Silvius Stanciu - sstanciu@ugal.ro 


\section{Introduction}

The adaptation of national food security policies in the context of the African Swine Fever epidemic outbreak (ASF) is a matter of utmost importance for national officials, economic agents and Romanian consumers, given the fact that during 2005-2015 Romania has been successively affected by the outbreak of zoo technical epidemics with a major impact on food production: Avian Flu AH1N1 (2005-2006), Swine Flu H1N1 (2009), Scrapia (2002-2011) or Bluetongue (2014-2015) (Stanciu, 2015; Stanciu and Sârbu, 2015; Stanciu and Sârbu, 2014).

Starting with the summer of 2018 , Romania faced the ASF epidemic, a critical food security incident that severely affected the national pork sector, limiting the supply of domestic products to the national and foreign markets. From an economic point of view, the effects of the crisis were much deeper, due to the decrease in the consumption of pork from the Romanian production and the increase of intra-Community imports. Applying national measures to support producers to mitigate the effects of the epidemic and to compensate businesses or individual households in areas with high epidemiological impact has led to significant costs at the level of the national budget.

Through the researches, the authors aimed to quantify the economic effects of the ASF and to develop a mathematical model of food sustainability, based on the application of statistical analysis systems, which are of practical importance in the adaptation of food security strategies at national level. The proposed statistical model can be generalized as a national food policy management tool in the context of the emergence of serious epidemiological incidents at national level in recent years.

In order to meet the objectives, the authors used the bibliographic documentation, evaluated the statistical models proposed by the recognized specialists in the field, systematized the available data in the national databases and proposed their own food sustainability model which is presented and applied in this paper.

The model is functional and allows periodic assessment of national food security from an economic perspective based on information regarding the effects of ASF on swine farms provided by national institutions, the impact on the national economy, the reduction of pork consumption, the increase in the import quota or the need for financial allocations to compensate and limit the effects of the epidemiological crisis.

\section{Review of scientific literature}

In crisis, food policies suffer structural changes in the context of food insecurity as a result of the outbreak of food crises due to epidemic. In crisis situations, the issue of food security is emphasized, as one of the key points in the Millennium Development Goals (MDGs) as defined at the Global Summit of Food and Agriculture Organization of the United Nations (Häsler, Howe and Stärk, 2011; Bakardjieva Engelbrekt et al., 2018).

The analysis of the pork sector in Romania, made by Stanciu (2014) showed a slight trend of domestic production growth, mainly due to government incentives for producers, although there is an abundance of imported products from European countries, amid the restrictions imposed by the Russian Federation. According to the estimates made by the author, in 2019 Romania could become a regional exporter of pork. The main investments in swine breeding farms and specialized slaughterhouses were due to companies with Chinese and Dutch capital. 
Although the increase in domestic production was mainly based on intensive principles, by increasing the average weight of animals sacrificed in the slaughterhouse, the sector was dependent on imports of young animals destined to populate farms, in the conditions of the reduction of domestic livestock.

A source of food policy instability is the illegal import of food from areas where epidemics have been reported (Costard et al., 2013). The study by the cited authors revealed that illegal imports of meat and meat products may represent a significant risk factor in market destabilization, in the conditions of manifestation of the biological hazard and the uncontrolled action of the economic agents in the areas affected by the epidemic. The research highlighted the need to strengthen surveillance systems based on risk monitoring and on the implementation of epidemic prevention programs in the European Union.

Other authors (Fasina et al., 2012; Arias et al., 2018) highlighted the benefits of applying biosecurity measures to local and national economic development, correlated with the costs of eradicating outbreaks of African swine fever in swine farms from Africa. Although the application of biosecurity measures involves significant economic efforts, they have a direct impact on the spread of epizootic diseases, reducing the transversal effects on the local economy.

Assessments based on the cause-effect analysis have allowed simulation of the economic impact of ASF epidemics on the population of industrialized areas (Halasa et al., 2016; Rich and Perry, 2011). Research has shown a potential major economic impact of the epidemic. The method, based on the direct correlation between costs and exports, has shown that global losses between EUR 12 million and EUR 349 million may occur if the epidemic is triggered simultaneously in territorially dispersed outbreaks.

Other research has focused on the relevance of measures to prevent the spread of African swine fever in the European Union (Chenais et al., 2017; Jurado et al., 2018). The cited works highlighted the efficiency of programs for health education of farmers, the isolation of pests, the limitation of the negative impact on the environment or the application of effective measures for handling and destroying dead animals, including wild animals, within a maximum of 48 hours from killing.

The European Union has shown its readiness to assist Member States in identifying appropriate solutions and improving practical ways of administrative cooperation, including combating and limiting zoonotic epidemics that may affect the population (Grosu and Socoliuc, 2008).

An analysis of the Romanian meat sector by Stanciu, Rizea and Ilie (2015) highlighted the fragility of the Romanian meat sector in the critical food safety incidents and the high dependence of the domestic market on Community imports of meat and meat products. Research has demonstrated the vulnerability of local authorities in face of the emergence of epidemics in the livestock sector, the need for a pro-active approach to quantify the economic impact of a potential food safety crisis, and the determination of the economic and administrative measures needed to mitigate the medium-term and long-term negative effects on the national food sector.

Stanciu and Sârbu (2014) analysed the resilience of the food chain in Romania to critical incidents, highlighting its fragility, especially of the small companies involved in the processing and marketing of food. The outbreak of epidemics in the livestock sector can 
seriously affect domestic food production, increasing the dependence of the national food market on imports.

Drăgoi et al. (2018) have shown that the radical transformation of national agricultural systems, due to the need for harmonization with the requirements of the European agricultural model, has led to a significant change in agro-food products markets, with important effects on food trade and food security.

Competition, competitiveness and the need for a favourable image of the market have prompted companies to become increasingly sensitive to environmental issues, critical food safety incidents or epidemics that may affect population health and biological assets (Bostan et al., 2013).

\section{Presentation of macroeconomic context of the African swine fever outbreak in Romania}

African Swine Fever (ASF) is due to the infection of swine livestock with the Pestivirus virus from the Flaviviridae family, the usual way of spreading is from an infected animal, domestic pig or wild boar, to a healthy animal through direct contact (through the blood or secretions of the infected animal) or indirectly through the carrier visitors that enter the areas of swine breeding, trans placental infections or food waste used in pig feed. The most prevalent form of spread is represented by animals that consume infested meat and can keep the virus active for a long time. The disease incubation period is between 2 to 14 days and results in acute or chronic illness, with the most serious manifestations of the disease being congenital (where cerebral, pulmonary, or other congenital malformations) occur. Outbreaks are identified after the ASF has been established and verified on the basis of analysis bulletins.

The National Sanitary Veterinary and Food Safety Authority (NSVFSA) requires an epidemiological inquiry, followed by a plan of measures to control and combat the epidemic (ANSVSA, 2018). After the ASF outbreaks are established, the delimitation of the affected area, disinfection, pest control and stunning of diseased animals are carried out. Following the assessment of the eradication of the outbreak, steps may be taken to lift the restrictions following epizootic extinction by the use of sentinel animals that test the existence of the virus. National legislation in the field of biosecurity is harmonized with the provisions of the Council Directive 2001/89/EC (European Commission, 2012), transposed by NSVFSA Order 67/2005 (ANSVSA, 2005) and Romania's contingency plan for classical swine fever directly through the implementation of Council Directive 90/423/EEC 2016/429 (Consiliul Uniunii Europene, 2016) and European Commission Decision 91/42 (Comisia Europeana, 2000).

Although Romania has absorbed some of the European funds allocated to food safety, their medium-term or short-term effects on the reduction of the risks of zoonotic epidemics have been quite low (Cosmulese and Ciubotariu, 2017).

Biosecurity rules primarily address prevention and hygiene measures, and vaccination is not a useful method for reducing the spread of ASF. The actions of the authorities should be directed towards the efficient management of outbreaks of disease, for a quick liquidation and to prevent the epidemic from spreading. 
According to the official information, the major epidemic affected in Romania at the beginning of November a number of 18 counties, the map of spreading outbreaks of the epidemic being presented in Figure no. 1 (ANSVSA, 2018).

The link between outbreaks in households (Figure no. 1) and wildlife propagation factors (number of cases identified in the affected counties) is heterogeneous. Thus, the counties of the north-western part of the country were particularly affected by the migration of diseased animals from Hungary (with a $138.0 \%$ affectation rate of household / wild animal infected), while in the South-East of Romania the average rate of damage due contact with wild animals was only $16.65 \%$, the Danube being a natural obstacle to the epidemic ASF.

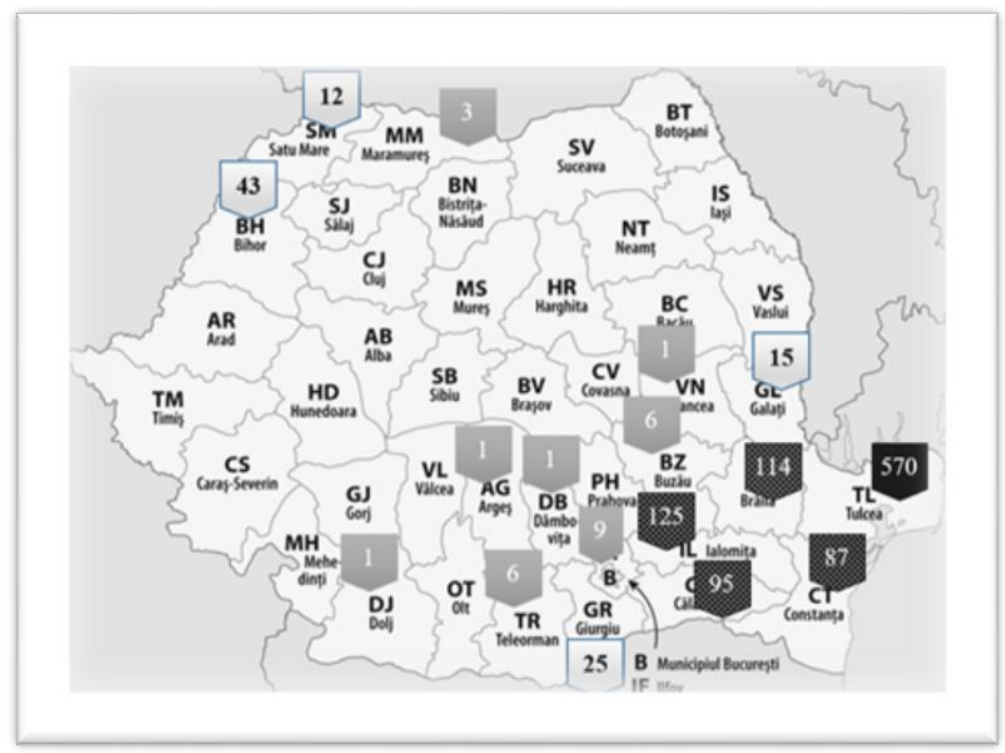

Figure no. 1: Distribution of outbreaks of ASF and number of households affected in Romania

Source: Authors' representation based on ANSVSA, 2018

According to the NSVFSA, the average number of infected wild animals found in the SouthEast Region of Romania during 8-23.11.2018 was 10 animals / county, mentioning that in the counties of Călărași, Ialomița, Teleorman and Tulcea the average number of animals exceeded by far the county average at national level (ANSVSA, 2018).

The maximum level of risk was registered on 23.11.2018 in Tulcea County, with 73 infected wild-animal heads/81 households (table no. 1).

A particular case is Teleorman County, where the maximum number of infected households is 7, while the number of identified infected wild animals reached 56 on 23.11.2018. In this situation, the infestation rate was 8 times higher among wild animals than among households, indicating a potential expansion of outbreaks in this area over the next period, in the absence of effective measures to limit the spread of the epidemic. The affectation by households infected with the ASF virus is presented in table no. 1 on the basis of the relative distribution series for 9 counties of the 18 affected (marked distinctly on the risk map in Figure no. 1). 
Table no. 1: Households affected by ASF by counties

\begin{tabular}{|l|r|r|r|}
\hline \multirow{2}{*}{ Counties } & \multicolumn{3}{|c|}{ Distribution /Significant affectation } \\
\cline { 2 - 4 } & $\mathbf{8 . 1 1 . 2 0 1 8}$ & $\mathbf{1 4 . 1 1 . 2 0 1 8}$ & $\mathbf{2 3 . 1 1 . 2 0 1 8}$ \\
\hline Bihor & $3.22 \%$ & $3.20 \%$ & $3.98 \%$ \\
\hline Brăila & $10.22 \%$ & $10.24 \%$ & $10.56 \%$ \\
\hline Călărași & $8.33 \%$ & $8.27 \%$ & $8.80 \%$ \\
\hline Constanța & $8.04 \%$ & $8.08 \%$ & $8.06 \%$ \\
\hline Galaţi & $1.32 \%$ & $1.41 \%$ & $1.39 \%$ \\
\hline Giurgiu & $2.27 \%$ & $2.35 \%$ & $2.31 \%$ \\
\hline Ialomița & $11.83 \%$ & $11.75 \%$ & $11.57 \%$ \\
\hline Satu-Mare & $1.14 \%$ & $1.13 \%$ & $0.56 \%$ \\
\hline Tulcea & $53.64 \%$ & $53.57 \%$ & $52.78 \%$ \\
\hline
\end{tabular}

Source: Authors' calculations according to the information found on ANSVSA, 2018

Authorities have made efforts to limit the spread of the phenomenon and for the 1,120 outbreaks identified they have applied measures to kill animals infected with ASF in commercial farms and households in a total number of 361,397 swine (out of which 297,618 swine in commercial farms and 63,779 household swine). The vast majority of the infected swine subjected to slaughter belong to households, where the hygiene measures and the prevention of virus spreading are precarious (Figure no. 2).

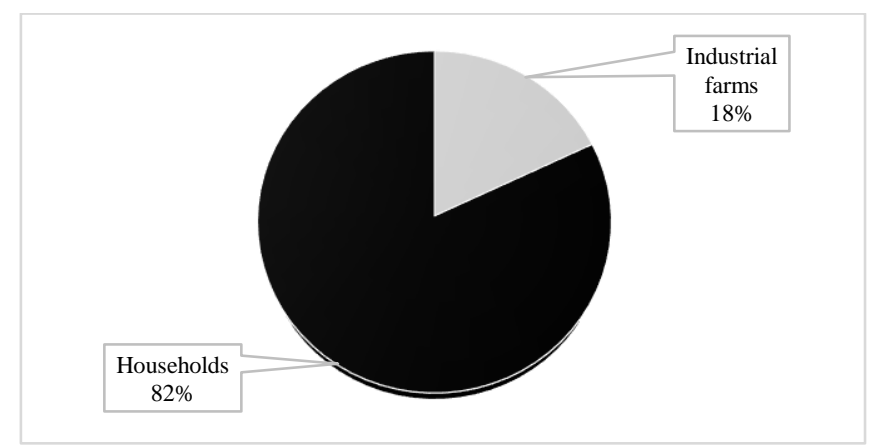

Figure no. 2: Distribution of slaughtered pigs infested with ASF between households and commercial units

Source: Authors' calculations according to the information found on ANSVSA, 2018

Industrial farms units specialized in raising pigs which have applied the recommended preventive measures were less affected compared to non-professional farms.

At the level of eradication of infected wild animals, there were 300 confirmed cases (dead and hunted wild boars). The extreme measures taken to avoid the spread of the virus led to the killing of a total of 3,945 wild swine. This action, although it increased the biosecurity in the area, it significantly reduced the fauna of the affected counties. In order to restore the natural balance and the hunting fund, further measures will be needed, which will involve economically the local authorities. 


\section{Research methodology}

The aim of the research was to create a model of food sustainability that would generate the premises for optimizing the indicators of food impairment. This goal involved defining research objectives as follows:

- $\mathbf{O 1}$ - assessment of the current situation of affecting the national economy in relation to the epidemic crisis in Romania;

- $\mathbf{O 2}$ - identifying quantifiable factors and improving them to optimize the management offood policies in the context of the epidemiological crisis;

- $\mathbf{O 3 ~ - ~ i d e n t i f i c a t i o n ~ o f ~ f i n a n c i a l ~ s t r e s s o r s ~ a n d ~ o p t i m i z a t i o n ~ m e a s u r e s ~ t o ~ l i m i t ~ t h e ~}$ economic effects of the epidemiological crisis;

- 04 - conceptualizing a statistical model of food sustainability and assessing its impact on future food policies.

In order to achieve these research objectives, the study of the scientific literature was used by identifying and evaluating models based on biosecurity measures (Fasina et al., 2012; Arias et al., 2018) or on cause-effect effect analysis to predict the economic impact of epidemics (Halasa et al., 2016; Rich and Perry, 2011) developed internationally.

Analytical methods were used to study, analyse and interpret the specific information provided by the national data bases of the National Sanitary Veterinary and Food Safety Authority - NSVFSA (ANSVSA, 2018), the National Institute of Statistics (Institutul National de Statistica, 2018) and centralized platforms in the systematization of financial information reported by the companies in the branch (Topfirme.ro, 2018).

This information has been systematized, analysed and interpreted by using the Excel computing software and the Microsoft Office software package. The results of the database study were statistically processed for modelling using the Gretl statistical software version 2018.

In order to calculate the financial impact of African swine fever virus infestation in Romanian farms, a financial impact vector model based on the information published by NSVFSA (ANSVSA, 2018) on the total number of farms affected, the number of households affected in the total holdings, respectively the total amounts given as compensation according to formula:

$I_{e j}=\alpha_{j} * f_{j}=\frac{E_{j}-E_{g j}}{\sum_{j=1}^{12}\left(E_{j}-E_{g j}\right)} * \frac{F_{j}}{\sum_{j=1}^{12} F_{j}} I_{e j}=\alpha_{j} * f_{j}=\frac{E_{j}-E_{g j}}{\sum_{j=1}^{12}\left(E_{j}-E_{g j}\right)} * \frac{F_{j}}{\sum_{j=1}^{12} F_{j}}$

where:

$I_{e j}$ - the aggregate index of damaging commercial farms following the outbreak of African swine fever virus in Romania in the 12 counties where compensation was granted after the extinguishing of outbreaks;

$\alpha_{j}$ - the zonal index for affecting commercial farms following the outbreak of African swine fever virus in Romania in the 12 counties where compensation was granted after the extinguishing of outbreaks;

$f_{j}$ - financial index for affecting commercial farms following the outbreak of African swine fever virus in Romania in the 12 counties where compensation was granted after the extinguishing of outbreaks; 
$E_{j}-$ total farms affected at county level;

$E_{g j}$ - total affected households of the total affected farms at county level;

$F_{j}$ - the amount of compensation for the slaughter of animals intended for extinguishing the outbreaks of African swine fever.

For the elaboration of the statistical model of food sustainability, the following working hypotheses were formulated:

- H1 - the epidemiological crisis from external factors is able to significantly affect food policy in direct dependence on the ineffectiveness of biosecurity measures;

- H2 - the existence of a preventative behaviour, based on educating the producers, can limit to minimizing the effects of an epidemiological crisis;

- H3 - the creation of a genetic reserve fund in crisis situations can mitigate the negative impact of the epidemiological crisis on food policies;

- H4 - the financial effort in epidemiological crisis situations is directly proportional to the latency of the crisis and indirectly proportional to the dispersion / density of the farms in the territory;

- H5 - the food sustainability model chosen for periods of epidemic crisis has a significant impact on future food policies.

The following indicators were used to build the model:

- the average trend of evolution in a relevant historical period of 10 years of the swine livestock-Es;

- the dynamics of the numbers of swine livestock during epidemic crisis - Ds;

- dispersion in the territory of the swine livestock from affected areas - $\boldsymbol{T} \mathbf{s}$;

- the aggregate index of damaging commercial farms following the outbreak of African swine fever virus in Romania in the 12 counties where compensation was granted after the extinguishing of outbreaks $-I_{e j}$;

- the amount of financial impact attributed to food policy changes following the epidemiological crisis-PAs.

Data taken from the NSVFSA website (2018) were systematized and processed to highlight the amount of financial impact associated with food policy changes following the epidemic crisis, were modelled using the GRETL statistical software, version 2018, using the smallest squares method, conceptualizing a statistical model of food sustainability whose multiplicative equation is defined by formula (2):

$\mathrm{PA}_{\mathrm{s}}=+0,0588 * \mathrm{MCSE} 2017-0,0627 * \mathrm{MCSE} 2018+0,0744 * \mathrm{DESP} 2018$

$\mathrm{n}=12, \mathrm{R}$-squared $=0,849$ (standard errors in brackets) 
Where:

- $\mathrm{PA}_{\mathrm{s}}$ dependent variable, respectively the amount of financial impact attributed to food policy changes following the epidemiological crisis;

- Regressor:

- MCSE2017 - Average of heads of pigs / farm in county 2017;

- MCSE2018 - Average of heads of pigs / farm in county 2018; the dynamics of the swine livestock during epidemic crisis - Ds = MCSE2018/ MCSE2017;

- DESP2018 - Amount of compensations granted (millions of euro).

The statistical model of food sustainability was generated by statistical tests based on the smallest squares (OLS), at high values of significance thresholds $(* * *)$ for financial stress regressor (DESP 2018 (Model 1).

\section{Model 1 - OLS using observations 1-12, Dependent variable: Pas}

\begin{tabular}{|c|c|c|c|c|c|}
\hline & Coefficient & $\begin{array}{l}\text { Standard } \\
\text { error }\end{array}$ & t-ratio & $p$-value & \\
\hline MCSE2017 & 0.0587663 & 0.294656 & 0.1994 & 0.8464 & \\
\hline MCSE2018 & -0.0626860 & 0.320114 & -0.1958 & 0.8491 & \\
\hline DESP2018 & 0.0744376 & 0.0164870 & 4.515 & 0.0015 & $* * *$ \\
\hline $\begin{array}{l}\text { Average of dependent } \\
\text { variables }\end{array}$ & 0.599208 & \multicolumn{3}{|c|}{$\begin{array}{l}\text { Standard variation of the dependent } \\
\text { variable }\end{array}$} & 0.950016 \\
\hline Sum of residual squares & 2.142902 & \multicolumn{3}{|c|}{ Standard error of regression } & 0.487955 \\
\hline R- square not centred & 0.849478 & \multicolumn{3}{|c|}{ R-square centred } & 0.784152 \\
\hline $\mathrm{F}(3,9)$ & 16.93061 & \multicolumn{3}{|l|}{ P-value (F) } & 0.000482 \\
\hline Probability of log & -6.690787 & \multicolumn{3}{|c|}{7 Akaike Criterion } & 19.38157 \\
\hline Schwarz Criterion & 20.83629 & \multicolumn{3}{|c|}{ Hannan-Quinn Criterion } & 18.84299 \\
\hline
\end{tabular}

The graphical representation of statistical tests for residual normality by means of distribution and prediction diagrams revealed that under the null hypothesis: the error is normally distributed (Figure no. 3).

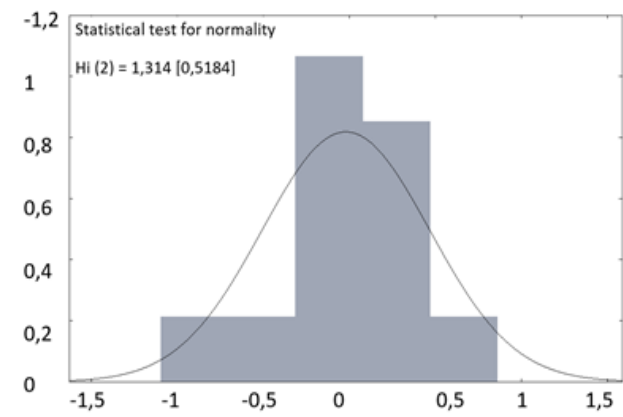

a)

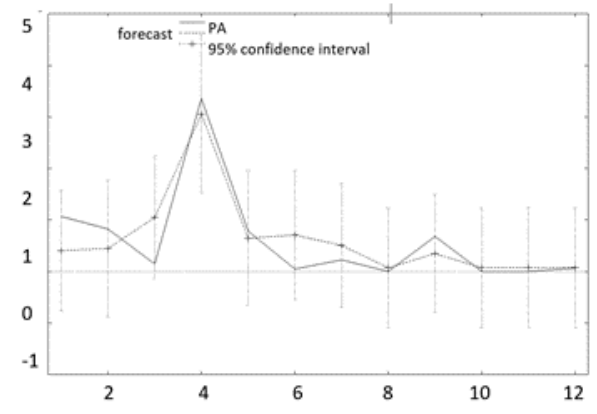

b)

Figure no. 3: The statistical test of the normality of the distribution of the dependent variable and the dependent variable forecast diagram for the $95 \%$ confidence interval, $t(9,0.025)=\mathbf{2 . 2 6 2}(\mathrm{a})$; Amount of financial impact attributed to changes in food policy following the epidemiological crisis - Step (b) 
The statistical representativeness of the model, the assessment of the hypothesis confirmation and the relationship with the study objectives were addressed in the results and discussions chapter.

\section{Results and discussions}

At the time of the study, according to NSVFSA data, in Romania, 18 counties were affected by ASF, 12 registering significant losses of pigs and in which producers benefited from significant state compensation (ANSVSA, 2018). On the whole, 7,130 production units (ANSVSA, 2018) were affected at the level of the 12 severely damaged counties. The total value of the compensations granted to the pig farmers by the Romanian state on 23.11.2018 reached 205,580,960 RON (approx. 44,691,500 euros), the largest amount being allocated to the farmers in the counties of Braila and Tulcea (which have cumulated about $94 \%$ of total national compensation) (Table no. 2).

Table no. 2: Zonal affectation of the swine farms infected with the ASF virus and the compensations granted by counties (value and percentage)

\begin{tabular}{|c|c|c|c|}
\hline \multirow[t]{2}{*}{ County } & \multirow{2}{*}{$\begin{array}{l}\text { Affected farms } \\
\text { (on 28.11.2018) }\end{array}$} & \multicolumn{2}{|c|}{ Compensations granted } \\
\hline & & RON & Share (\%) \\
\hline Satu-Mare & 18 & 60,940 & 0.03 \\
\hline Bihor & 211 & 947,620 & 0.46 \\
\hline Tulcea & 1,141 & $45,681,430$ & 22.22 \\
\hline Brăila & 2,997 & $147,278,090$ & 71.64 \\
\hline Constanta & 833 & $3,688,100$ & 1.79 \\
\hline Ialomita & 2,389 & $6,531,000$ & 3.18 \\
\hline Galaţi & 83 & 248,000 & 0.12 \\
\hline Ilfov & 6 & 71,640 & 0.03 \\
\hline Călărași & 214 & 898,000 & 0.44 \\
\hline Teleorman & 7 & 31,510 & 0.02 \\
\hline Vrancea & 1 & 7,000 & 0.00 \\
\hline Giurgiu & 30 & 137,630 & 0.07 \\
\hline Total & 7,930 & $205,580,960$ & 100.00 \\
\hline
\end{tabular}

Source: Author calculations according to information taken from ANSVSA, 2018

From an economic point of view, the value of the compensation paid to swine breeders at the time of the analysis was about $30 \%$ of the value of the global profit recorded by the sector in 2017. According to NSVFSA, on 28.11.2018 most of the infected and slaughtered swine in commercial farms was registered in Tulcea, Brăila and Călăraşi counties. Thus, in 15 units specialized in swine breeding located on the territory of these counties there were 297,434 cases of diseased or suspected ASF (ANSVSA, 2018).

Slaughtering infected specimens was carried out in compliance with the legal provisions on the protection of animals using the captive bullet method (139,386 pig heads) and narcotic gas $\mathrm{CO}_{2}$ (149,992 pig heads).

A total of 8,056 animals died due to the effects of ASF. The distribution of the slaughtering methods used in Romania is shown in Figure no. 4. 


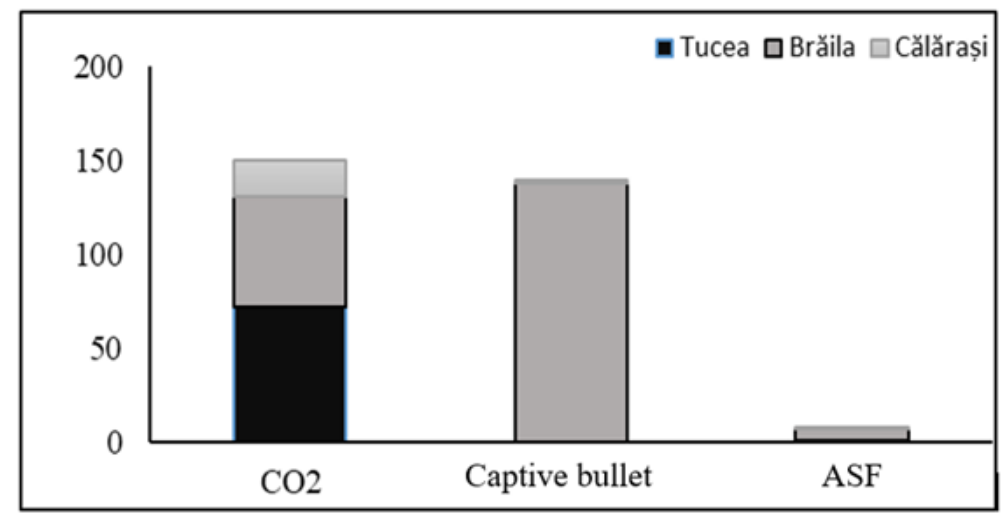

Figure no. 4: Situation of rendering and slaughtering animals infested with ASF in industrial farms

Source: Author calculations according to information taken from ANSVSA, 2018

Taking into account an average value of $9.5 \mathrm{RON} / \mathrm{kg}$ of meat for compensations for slaughtered pigs, their distribution for the slaughtered swine livestock in Tulcea, Brăila and Călăraşi counties is presented in table no. 3 .

Table no. 3: Compensation for slaughtered swine in commercial farms (RON)

\begin{tabular}{|l|r|r|r|}
\hline County & $\begin{array}{l}\text { Compensation for swine } \\
\text { slaughtered using CO2 }\end{array}$ & $\begin{array}{l}\text { Compensation for swine } \\
\text { slaughtered using }\end{array}$ & $\begin{array}{l}\text { Compensation for swine } \\
\text { which died of ASF }\end{array}$ \\
\hline Tulcea & 685,102 & 0.00 & 5,415 \\
\hline Brăila & 551,133 & $1,309,718$ & 60,534 \\
\hline Călăraşi & 188,024 & 14,450 & 10,583 \\
\hline $\begin{array}{l}\text { Total RON } \\
(\%)\end{array}$ & $1,424,259$ & $1,324,167$ & 76,532 \\
\cline { 2 - 4 } & 50.42 & 46.87 & 2.71 \\
\hline
\end{tabular}

Source: Author calculations according to information taken from ANSVSA, 2018

From an economic point of view, the value of the compensation paid to swine breeders at the time of the analysis was about $30 \%$ of the value of the global profit recorded by the sector in 2017.

According to NSVFSA, on 28.11.2018 most of the infected and slaughtered swine in commercial farms was registered in Tulcea, Brăila and Călăraşi counties (ANSVSA, 2018). Thus, in 15 units specialized in pig breeding located on the territory of these counties, there were 297,434 cases of diseased or suspected ASF.

The sacrifice of the infected specimens was carried out in compliance with the legal provisions on the protection of animals using the captive bullet method (139,386 pig heads) and $\mathrm{CO}_{2}$ (149,992 pig heads). A total of 8,056 animals died due to the effects of ASF. The distribution of the slaughtering methods used in Romania is shown in Figure no. 4.

The value of slaughtered slaughtering was 44.6 million euros, accounting for $5 \%$ of all businesses in the sector. The industrial pig farms in the 12 counties affected by the ASF reported a net turnover of EUR 355.6 million in 2017 and a profit of EUR 72.45 million, providing around 2.500 jobs (Table no. 4 ). 
Table no. 4: Distribution of the economic performance of the pig breeding sector before the outbreak of the ASF (23.11.2018)

\begin{tabular}{|l|r|r|r|r|r|r|}
\hline \multirow{2}{*}{$\begin{array}{c}\text { Affected } \\
\text { counties }\end{array}$} & \multicolumn{2}{|c|}{ Turnover per county } & \multicolumn{2}{c|}{$\begin{array}{c}\text { Number of } \\
\text { employees }\end{array}$} & \multicolumn{2}{c|}{ Profit by county } \\
\cline { 2 - 8 } & million euro & Weight $\mathbf{( \% )}$ & Total & Weight (\%) & million euro & Weight (\%) \\
\hline Satu-Mare & 36.20 & 1.00 & 263 & 0.43 & 4.900 & 2.03 \\
\hline Bihor & 23.40 & 0.36 & 136 & 0.11 & 1.900 & 0.43 \\
\hline Tulcea & 6.60 & 0.40 & 120 & 0.41 & 0.088 & 0.07 \\
\hline Brăila & 78.90 & 4.21 & 520 & 1.29 & 3.600 & 2.16 \\
\hline Constanța & 19.80 & 0.20 & 264 & 0.20 & 0.210 & 0.03 \\
\hline Ialomița & 1.10 & 0.06 & 24 & 0.09 & 0.063 & 0.05 \\
\hline Galați & 6.20 & 0.12 & 109 & 0.14 & 0.466 & 0.18 \\
\hline Ilfov & 35.60 & 0.17 & 276 & 0.16 & 23.400 & 1.69 \\
\hline Călărași & 27.60 & 1.43 & 302 & 1.19 & 4.500 & 2.91 \\
\hline Teleorman & 6.90 & 0.51 & 248 & 0.89 & 0.025 & 0.02 \\
\hline Vrancea & 104.70 & 5.77 & 289 & 0.81 & 32.000 & 19.11 \\
\hline Giurgiu & 8.60 & 0.62 & 30 & 0.14 & 1.300 & 1.07 \\
\hline Total & 355.60 & 1.24 & 2,581 & 4.04 & 72.452 & 2.64 \\
\hline
\end{tabular}

Source: Authors, according to information from Topfirme.ro, 2018

The value of the aggregate index calculated according to formula no. 1 ranges between $68.91 \%$ (maximum value) and $0.01 \%$ (minimum value). The economic damage calculated after applying the aggregate index on the main financial indicators (turnover, number of employees, taxable profit) is presented in table no. 5 .

Table no. 5: Histogram distribution of the financial impact on the commercial farms affected by the epidemic (estimation for the year 2018 at county level)

\begin{tabular}{|l|r|r|r|r|r|r|r|}
\hline County & \multicolumn{1}{|c|}{$\begin{array}{c}\text { Affected } \\
\text { farms }\end{array}$} & $\begin{array}{l}\text { Affected } \\
\text { households }\end{array}$ & $\begin{array}{c}\text { Compensation } \\
\text { (mil. euro) }\end{array}$ & $\begin{array}{l}\text { Iej } \\
(\%)\end{array}$ & $\begin{array}{c}\text { Turnover } \\
\text { (million euro) }\end{array}$ & $\begin{array}{c}\text { Number } \\
\text { of } \\
\text { employees }\end{array}$ & $\begin{array}{c}\text { Profit } \\
\text { (mil. } \\
\text { euro) }\end{array}$ \\
\hline Satu-Mare & 18 & 6 & 0.01 & 0.02 & 24.13 & 175 & 3.27 \\
\hline Bihor & 211 & 43 & 0.22 & 0.37 & 18.63 & 108 & 1.51 \\
\hline Tulcea & 1141 & 570 & 10.43 & 11.12 & 3.30 & 60 & 0.04 \\
\hline Brăila & 2997 & 114 & 33.46 & 68.91 & 75.90 & 500 & 3.46 \\
\hline Constanța & 833 & 87 & 0.84 & 1.61 & 17.73 & 236 & 0.19 \\
\hline Ialomița & 2389 & 125 & 1.50 & 3.01 & 1.04 & 23 & 0.06 \\
\hline Galați & 83 & 15 & 0.06 & 0.10 & 5.08 & 89 & 0.38 \\
\hline Ilfov & 6 & 6 & 0.02 & 0.00 & 0.00 & 0.00 & 0.00 \\
\hline Călărași & 214 & 95 & 0.20 & 0.24 & 15.35 & 168 & 2.50 \\
\hline Teleorman & 7 & 7 & 0.01 & 0.00 & 0.00 & 0 & 0.00 \\
\hline Vrancea & 1 & 1 & 0.00 & 0.00 & 0.00 & 0 & 0.00 \\
\hline Giurgiu & 30 & 25 & 0.03 & 0.01 & 1.43 & 5 & 0.22 \\
\hline Total & 7930 & 1094 & 46.77 & 45.73 & 162.60 & 1,365 & 11.64 \\
\hline
\end{tabular}

Source: Authors calculations based on data from ANSVSA, 2018 
Based on the estimated financial impact and calculated in table no. 5, worth $€ 162.6$ million, a major impact on national food policies can be anticipated for the year 2019, both at quantitative level, by increasing net imports of pork and at qualitative level, by the need to move the specific weight consumption of the pork to other types of meat (chicken, beef, etc.), to alternative protein variants (vegetable protein) or to additional amino acid intake (Figure no. 5).

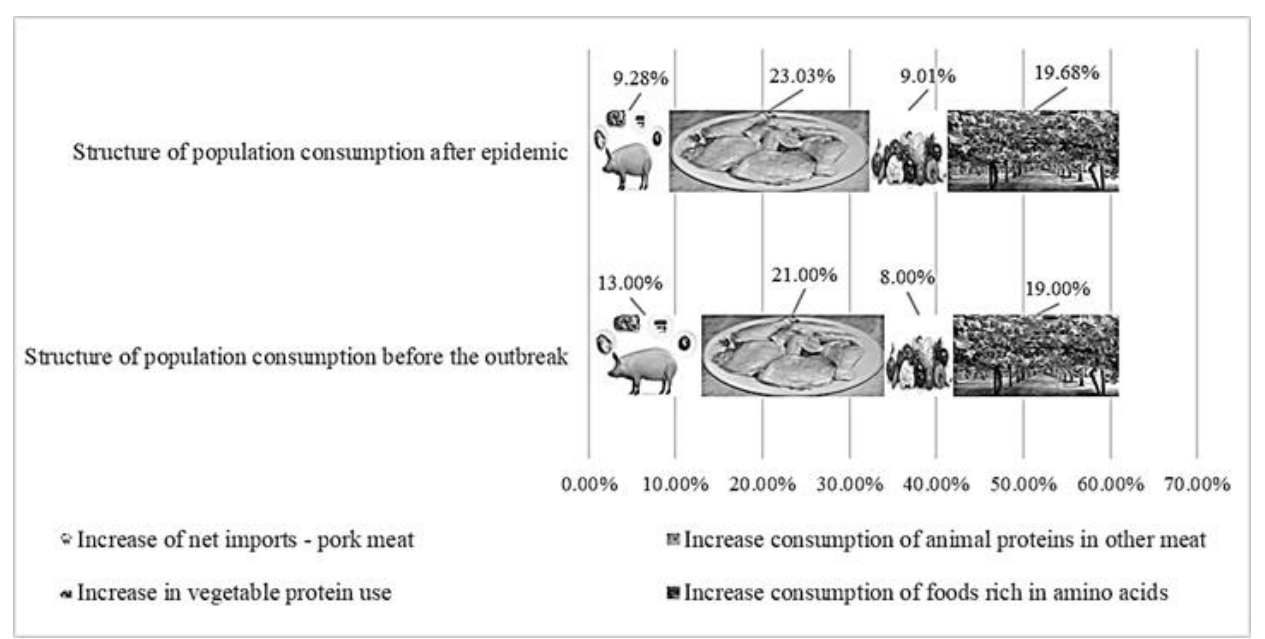

Figure no. 5: Dynamics of the structure of consumption of Romanian population before and after the outbreak of ASF

In this context, there is a decrease in the food availability for Romanian consumers in the pork segment, and there is a need for concerted action by the authorities on the rehabilitation of livestock and the protection of the consumer's interests in the medium and long term. For the calculation of the statistical model of food sustainability, information available on the Tempo online portal, published by the National Institute of Statistics (Institutul National de Statistica, 2018), on the national sine livestock on $1^{\text {st }}$ May 2018, by weight groups and economic destination, as well as their evolution during the period 2009 - 2018. The data processing from the national statistics allowed the calculation of the specific indicators: the average evolution trend of the swine livestock in a relevant historical period of 10 years (Es), the dynamics of the swine livestock during the epidemic crisis period (Ds) and the dispersion in the territory of the swine in affected areas (Ts) (Tables no. 6 and no. 7).

Table no. 6: Average trend of the swine livestock-(Es) in the last 10 years

\begin{tabular}{|l|r|r|r|r|r|r|r|r|r|r|}
\hline $\begin{array}{l}\text { Dynamics of swine } \\
\text { livestock on 1st May }\end{array}$ & $\begin{array}{c}2010 / \\
2009 \\
2018, \text { by weight groups }\end{array}$ & $\begin{array}{c}2011 / \\
2010 \\
(\%)\end{array}$ & $\begin{array}{c}2012 / \\
2011 \\
(\%)\end{array}$ & $\begin{array}{c}2013 / \\
2012 \\
(\%)\end{array}$ & $\begin{array}{c}2014 / \\
2013 \\
(\%)\end{array}$ & $\begin{array}{c}2015 / \\
2014 \\
(\%)\end{array}$ & $\begin{array}{c}2016 / \\
2015 \\
(\%)\end{array}$ & $\begin{array}{c}2017 / \\
2016 \\
(\%)\end{array}$ & $\begin{array}{c}2018 / \\
2017 \\
(\%)\end{array}$ & $\begin{array}{c}2018 / \\
2009 \\
(\%)\end{array}$ \\
\hline Swine, total & 97.83 & 97.79 & 99.90 & 98.57 & 99.82 & 103.11 & 98.18 & 98.07 & 92.04 & 85.93 \\
\hline piglets under 20 kg & 97.29 & 92.32 & 99.71 & 103.42 & 100.09 & 101.12 & 99.46 & 96.34 & 90.62 & 81.39 \\
\hline piglets $20-49 \mathrm{~kg}$ & 97.22 & 95.89 & 101.83 & 100.88 & 98.23 & 101.87 & 94.26 & 97.85 & 92.09 & 81.39 \\
\hline Pigs at fattened, total & 98.60 & 102.95 & 97.62 & 93.84 & 102.23 & 105.77 & 101.62 & 99.65 & 93.83 & 95.55 \\
\hline$-50-80 \mathrm{~kg}$ & 97.06 & 101.65 & 95.28 & 90.55 & 101.86 & 107.32 & 97.54 & 95.85 & 90.07 & 78.35 \\
\hline$-81-110 \mathrm{~kg}$ & 103.54 & 103.10 & 103.40 & 97.14 & 103.45 & 103.03 & 111.98 & 101.74 & 101.14 & 131.68 \\
\hline - over $110 \mathrm{~kg}$ & 100.13 & 142.19 & 107.65 & 135.74 & 101.04 & 99.31 & 104.73 & 138.46 & 97.92 & 296.42 \\
\hline
\end{tabular}




\begin{tabular}{|l|r|r|r|r|r|r|r|r|r|r|}
\hline $\begin{array}{l}\text { Dynamics of swine } \\
\text { livestock on 1st May } \\
\begin{array}{l}\text { 2018, by weight groups } \\
\text { and economic destination }\end{array}\end{array}$ & $\begin{array}{c}2010 / \\
(\%)\end{array}$ & $\begin{array}{c}2011 / \\
(\%)\end{array}$ & $\begin{array}{c}2012 / \\
(\%)\end{array}$ & $\begin{array}{c}2013 / \\
(\%)\end{array}$ & $\begin{array}{c}2014 / \\
(\%)\end{array}$ & $\begin{array}{c}2015 / \\
(\%)\end{array}$ & $\begin{array}{c}2016 / \\
(\%)\end{array}$ & $\begin{array}{c}2017 / \\
2 \%)\end{array}$ & $\begin{array}{c}2018 / \\
2017 \\
(\%)\end{array}$ & $\begin{array}{r}2018 / \\
2009 \\
(\%)\end{array}$ \\
\hline $\begin{array}{l}\text { Swine for breeding over } \\
50 \mathrm{~kg} \text {, total }\end{array}$ & 98.59 & 96.91 & 102.30 & 98.42 & 96.27 & 101.75 & 97.50 & 95.61 & 86.09 & 75.63 \\
\hline - boars & 110.59 & 87.91 & 85.99 & 98.86 & 72.75 & 115.79 & 108.25 & 71.41 & 100.47 & 54.07 \\
\hline Sows total & 98.21 & 97.23 & 102.83 & 98.41 & 96.92 & 101.46 & 97.25 & 96.24 & 85.81 & 76.32 \\
\hline - sows mounted & 100.78 & 100.34 & 108.88 & 97.98 & 97.77 & 104.27 & 97.93 & 98.92 & 84.54 & 90.06 \\
\hline -sows at first mount & 101.85 & 111.93 & 111.81 & 104.20 & 95.05 & 101.70 & 97.25 & 85.28 & 96.39 & 102.63 \\
\hline Sows unmounted & 95.29 & 93.48 & 95.00 & 99.03 & 95.67 & 97.26 & 96.14 & 91.87 & 88.06 & 60.66 \\
\hline- unmounted gilts & 108.67 & 87.98 & 96.58 & 101.03 & 100.74 & 93.92 & 89.34 & 84.97 & 89.31 & 59.84 \\
\hline
\end{tabular}

Source: Authors calculations based on Institutul National de Statistica, 2018

Table no. 7: Differences in the evolution between annual mean rates and rates during the outbreak of epidemic period related to the dynamics of swine livestock

\begin{tabular}{|l|r|r|r|}
\hline $\begin{array}{l}\text { Dynamics of swine livestock on 1st May } \\
\text { destination }\end{array}$ & $\begin{array}{c}\text { Annual } \\
\text { average } \\
(\%)\end{array}$ & $\begin{array}{c}\text { Total rate of evolution of } \\
\text { the livestock during 2009- } \\
2018(\%)\end{array}$ & $\begin{array}{r}\text { Rate of evolution of } \\
\text { livestock 2018/2017 } \\
(\%)\end{array}$ \\
\hline Swine, total & 98.37 & -14.07 & -7.96 \\
\hline Pupiglets under 20 kg & 97.82 & -18.61 & -9.38 \\
\hline Ppiglets $20-49 \mathrm{~kg}$ & 97.79 & -18.61 & -7.91 \\
\hline Pigs at fattened, total & 99.57 & -4.45 & -6.17 \\
\hline-50 - 80 kg & 97.46 & -21.65 & -9.93 \\
\hline$-81-110 \mathrm{~kg}$ & 103.17 & 31.68 & 1.14 \\
\hline - over 110 kg & 114.13 & 196.42 & -2.08 \\
\hline Swine for breeding over 50 kg, total & 97.05 & -24.37 & -13.91 \\
\hline- boars & 94.67 & -45.93 & 0.47 \\
\hline Sows , total & 97.15 & -23.68 & -14.19 \\
\hline - sows mounted & 99.05 & -9.94 & -15.46 \\
\hline -sows at first mount & 100.61 & 2.63 & -3.61 \\
\hline Sows unmounted of which & 94.65 & -39.34 & -11.94 \\
\hline- unmounted gilts & 94.73 & -40.16 & -10.69 \\
\hline
\end{tabular}

Source: Authors calculations based on Institutul National de Statistica, 2018

Complex calculations of the distribution of livestock average held in commercial farms have been made after the weighting of the existing livestock on May 1st, by weight groups and economic destination with the average livestock distribution in the commercial farms and households, the data from Table no. 8 being thus obtained.

Table no. 8: Amount of financial impact on food policy changes after epidemic crisis - PAs

\begin{tabular}{|c|c|c|c|c|c|c|c|c|c|c|c|c|}
\hline Affected counties/Indicator & 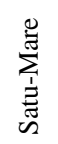 & $\stackrel{5}{\stackrel{0}{0}}$ & $\underset{\mathscr{J}}{\stackrel{\Xi}{\Xi}}$ & 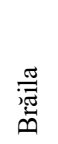 & 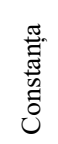 & $\begin{array}{l}\text { 売 } \\
\text { 总 } \\
\text { 志 }\end{array}$ & $\frac{\pi}{\pi}$ & $\stackrel{\vec{\varrho}}{\stackrel{G}{=}}$ & 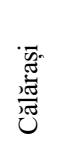 & 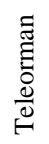 & $\begin{array}{l}\mathbb{J} \\
\stackrel{\Xi}{J} \\
>\end{array}$ & $\underset{\Xi}{\stackrel{\Xi}{\Xi}}$ \\
\hline $\begin{array}{l}\text { Average number of swine / farm in } \\
\text { county } 2009\end{array}$ & 404 & 482 & 303 & 583 & 543 & 574 & 496 & 101 & 337 & 101 & 101 & 101 \\
\hline $\begin{array}{l}\text { Average number of swine / farm in } \\
\text { county } 2010\end{array}$ & 395 & 472 & 297 & 570 & 531 & 562 & 486 & 99 & 330 & 99 & 99 & 99 \\
\hline
\end{tabular}




\begin{tabular}{|c|c|c|c|c|c|c|c|c|c|c|c|c|}
\hline Affected counties/Indicator & 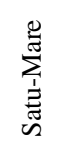 & $\stackrel{\vec{\circ}}{\frac{\mathscr{c}}{\oplus}}$ & $\underset{\mathscr{J}}{\stackrel{\Xi}{\Xi}}$ & 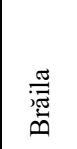 & 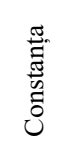 & 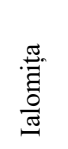 & 㒬 & $\stackrel{\text { 异 }}{=}$ & 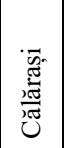 & 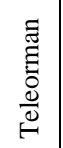 & 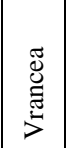 & $\begin{array}{l}\stackrel{\overrightarrow{0}}{\overrightarrow{0}} \\
\stackrel{\Xi}{\Xi}\end{array}$ \\
\hline $\begin{array}{l}\text { Average number of swine / farm in } \\
\text { county } 2011\end{array}$ & 386 & 462 & 290 & 558 & 519 & 549 & 475 & 97 & 322 & 97 & 97 & 97 \\
\hline $\begin{array}{l}\text { Average number of swine / farm in } \\
\text { county } 2012\end{array}$ & 386 & 461 & 290 & 557 & 519 & 549 & 474 & 97 & 322 & 97 & 97 & 97 \\
\hline $\begin{array}{l}\text { Average number of swine / farm in } \\
\text { county } 2013\end{array}$ & 381 & 455 & 286 & 549 & 511 & 541 & 468 & 95 & 317 & 95 & 95 & 95 \\
\hline $\begin{array}{l}\text { Average number of swine / farm in } \\
\text { county } 2014\end{array}$ & 380 & 454 & 285 & 548 & 510 & 540 & 467 & 95 & 317 & 95 & 95 & 95 \\
\hline $\begin{array}{l}\text { Average number of swine / farm in } \\
\text { county } 2015\end{array}$ & 392 & 468 & 294 & 565 & 526 & 557 & 481 & 98 & 327 & 98 & 98 & 98 \\
\hline $\begin{array}{l}\text { Average number of swine / farm in } \\
\text { county } 2016\end{array}$ & 385 & 459 & 289 & 555 & 517 & 547 & 473 & 96 & 321 & 96 & 96 & 96 \\
\hline $\begin{array}{l}\text { Average number of swine / farm in } \\
\text { county } 2017\end{array}$ & 377 & 450 & 283 & 544 & 507 & 536 & 464 & 94 & 315 & 94 & 94 & 94 \\
\hline $\begin{array}{l}\text { Average number of swine / farm in } \\
\text { county } 2018\end{array}$ & 347 & 415 & 261 & 501 & 466 & 493 & 427 & 87 & 290 & 87 & 87 & 87 \\
\hline Compensation granted (mil. euro) & 0.01 & 0.22 & 10.43 & 33.46 & 0.84 & 1.50 & 0.06 & 0.2 & 0.20 & 0.01 & 0.00 & 0.03 \\
\hline $\mathrm{I}_{\mathrm{ej}}(\%)$ & 0.02 & 0.37 & 11.12 & 68.91 & 1.61 & 3.01 & 0.10 & 0.00 & 0.24 & 0.00 & 0.00 & 0.01 \\
\hline PA (million euro), of which: & 1.07 & 0.82 & 0.15 & 3.36 & 0.78 & 0.05 & 0.22 & 0.00 & 0.68 & 0.00 & 0.00 & 0.06 \\
\hline Increase in net imports - pork & 0.73 & 0.57 & 0.10 & 2.31 & 0.54 & 0.03 & 0.15 & 0.00 & 0.47 & 0.00 & 0.00 & 0.04 \\
\hline $\begin{array}{l}\text { Increase consumption of animal } \\
\text { proteins of other types of meat }\end{array}$ & 0.24 & 0.19 & 0.03 & 0.77 & 0.18 & 0.01 & 0.05 & 0.00 & 0.16 & 0.00 & 0.00 & 0.01 \\
\hline $\begin{array}{l}\text { Increase in vegetable protein } \\
\text { consumption }\end{array}$ & 0.06 & 0.05 & 0.01 & 0.19 & 0.04 & 0.00 & 0.01 & 0.00 & 0.04 & 0.00 & 0.00 & 0.00 \\
\hline $\begin{array}{l}\text { Increased consumption of food rich } \\
\text { in amino acids }\end{array}$ & 0.03 & 0.02 & 0.00 & 0.09 & 0.02 & 0.00 & 0.01 & 0.00 & 0.02 & 0.00 & 0.00 & 0.00 \\
\hline
\end{tabular}

The analysis revealed that the triggering of the ASF significantly affected the pig farmers and processors in the South and South-Eastern regions of Romania, and considerable efforts were needed by the Romanian authorities to combat the crisis, prevent the spread of the outbreaks, reduce the factors risk and grant compensation for damages. These elements affected the welfare of households in the impact area and had a major negative effect on the economic agents in the field (Objective 1 of the research).

Improved and measurable factors have been identified in relation to optimizing the management of food policies in the context of the epidemiological crisis, namely preventive action based on the education of producers, and the creation of a genetic reserve fund to mitigate the negative impact of the epidemiological crisis on food policies (Hypothesis $\mathrm{H} 2$ and H3) (Objective 2 of the research)

Factors of financial stress have been identified in relation to the impact of swine farms and the amount of compensation granted by the Romanian state as a result of the crisis (Objective 3 of the research).

The statistical model of food sustainability has been conceptualized, valuable from the perspective of practical application and quantification of the links between food policies, applied on sustainability principles, and the financial effects of the crisis (Objective 4 of the research). 
Following modelling, a high statistical significance of the model was obtained $(84.9 \%)$, which confirms the hypotheses H1 and H4. The correlation between the DESP2018 and the dependent variable gives significance to the model by value $\mathrm{p}<0.001$ and demonstrates the hypothesis H5. Statistical tests have shown that in the null hypothesis the error is normally distributed (Test for residual normality) and heteroskedasticity is not present (Breusch-Pagan test), which confirms the homogeneity and validity of the model in relation to the proposed objective 2 and the hypotheses $\mathrm{H} 2$ and $\mathrm{H} 3$.

In this context, we find a worsening of the availability of food for swine, which requires authorities to take immediate measures to re-establish the swine livestock and protect consumer interests in the medium and long term.

\section{Conclusions}

Food policies in epidemiological crisis situations suffer significant structural changes in the context of an attempt to eradicate outbreaks, destroy genetic material and products destined for consumption, threatened by the epidemic, and it is necessary to adopt food sustainability measures in the context of shifting the specific weight of consumption options of the population towards other food alternatives and the need to supplement imports. The outbreak of the African swine fever epidemic has generated direct costs of fighting the epidemic, allocated from a special fund set up to fight epizootic diseases. The additional funds required were allotted from the government intervention fund. In addition to the direct costs incurred by the authorities, there is an indirect impact on commercial farms, quantified in the study at 162.6 million euros net turnover, respectively a loss in the financial result of 11.64 million euros. In addition, food policy changes were financially quantified to the amount of 7.19 million euros, of which 4.95 million euros increased net imports of pork, needed to stabilize the consumer market in the short term, 1.65 million euro funds allocated for the growth of reserves of other types of meat to ensure the population's protein requirement after the epidemiological impact of swine livestock, 0.41 million euro needed to cover potential differences in vegetable protein consumption and 0.18 million euro to ensure the additional consumption of foods rich in amino acids. Five working hypotheses (H1 - H5) were established in the study, which were demonstrated after the conceptualization of the food sustainability statistical model.

The proposed model has impact since it highlights the link between food policies applied on a sustainable basis and the financial effects of epidemic crises triggered in a given territory at a certain time and can be applied at local, regional, state level. The model is original, based on relevant statistical data taken for a representative 10-year interval.

The limits of the study are to apply the model to the particular situation of Romania, a potential development of the model being the increase of its complexity by quantifying the effects of critical food security incidents at the regional level.

\section{References}

ANSVSA, 2005. ORDIN nr. 67 din 12 iulie 2005 pentru aprobarea Normei sanitare veterinare cu privire la masurile pentru controlul pestei porcine clasice.

ANSVSA, 2018. Actualizarea situației privind evoluția Pestei Porcine Africane. [online] Available at: <http://www.ansvsa.ro/blog/actualizarea-situatiei-privind-evolutia-pesteiporcine-africane-14-12-2018/> [Accessed 14 December 2018]. 
Arias, M., Jurado, C., Gallardo, C., Fernández-Pinero, J. and Sánchez-Vizcaíno, J.M., 2018. Gaps in African swine fever: Analysis and priorities. Transboundary and Emerging Diseases, [ejournal] 65(S1), pp.235-247. Available through: Wiley Database <https://onlinelibrary.wiley. com/doi/abs/10.1111/tbed.12695> [Accessed 10 December 2018].

Bakardjieva Engelbrekt, A., Bremberg, N., Eriksson, M., Gullstrand, J., Jörgensen, C., Magnusson Sjöberg, C., Michalski, A., Nilsson, N., Noll, G., Österdahl, I., Oxelheim, L., Parker, C., Persson, T., Svensson, R., Wagnsson, C. and Widmalm, S., 2018. The European Union: Facing the Challenge of Multiple Security Threats. 1st ed. [e-book] London: Edward Elgar Publishing. Available at: Google Books <https://books.google.ro/books? hl=en\&lr=\&id=ECIWDwAAQBAJ\&oi=fnd\&pg= PR1\&ots=HSoePn1pbp\&sig=6j4D8RS3HrdSkENyq3KbnkBVnFw\&redir_esc $=y \# v=0$ on epage\&q\&f=false> [Accessed 02 December 2018].

Bostan, I., Grosu, V., Hlaciuc, E., Mates, D., Burciu, A., Socoliuc, M., Bunget, O., Domil, A., Moraru, M., Peres, C., Petrisor, B., Dumitrescu, A.-C., Artene, A. and Andronic, B., 2013. The environmental audit (EA) and the environmental balance sheet (EBS) in Romania. Journal of Food, Agriculture \& Environment, 11(3\&4), pp.2587-2592.

Chenais, E., Boqvist, S., Emanuelson, U., Brömssen, C. Von, Ouma, E., Aliro, T., Masembe, C. and Ståhl, K., 2017. Quantitative assessment of social and economic impact of African swine fever outbreaks in northern Uganda. Preventive Veterinary Medicine, [e-journal] 144, pp.134-148. http://dx.doi.org/10.1016/j. prevetmed.2017.06.002

Comisia Europeana, 2000. Decizia Comisiei 91/42 din 14 ianuarie 2000 de modificare a Deciziei 1999/246/CEE de aprobare a unor planuri de urgență pentru controlul pestei porcine clasice în situații neprevăzute. Jurnalul Oficial al Uniunii Europene, 30(03), pp.305-306.

Consiliul Uniunii Europene, 2016. Regulamentul (UE) 2016/429 al Parlamentului European și al Consiliului din 9 martie 2016 privind bolile transmisibile ale animalelor şi de modificare și de abrogare a anumitor acte din domeniul sănătății animalelor („Legea privind sănătatea animală”). Jurnalul Oficial al Uniunii Europene, [online] L 84(2), pp.1-208. Available at: <https://publications.europa.eu/en/ publication-detail/publication/ 9de141be-f714-11e5-abb1-01aa75ed71a1/language-en> [Accessed 12 December 2018].

Cosmulese, G. and Ciubotariu, M., 2017. An Overall Analysis on the Implementation of European Funds in Romania. The 30th International Business Information Management Conference. [online] Available at: <https://ibima.org/accepted-paper/an-overall-analysison-the-implementation-of-european-funds-in-romania> [Acessed 14 December 2018].

Costard, S., Jones, B.A., Martínez-López, B., Mur, L., de la Torre, A., Martínez, M., Sánchez-Vizcaíno, F., Sánchez-Vizcaíno, J.-M., Pfeiffer, D.U. and Wieland, B., 2013. Introduction of African Swine Fever into the European Union through Illegal Importation of Pork and Pork Products. PLOS ONE, [e-journal] 8(4), pp.1-12. https://doi.org/10.1371/journal.pone.0061104

Drăgoi, M.C., Andrei, J.V., Mieilă, M., Panait, M., Dobrotă, C.E. and Lădaru, R.G., 2018. Siguranţa și securitatea alimentară în românia - o analiză econometrică în contextul transformării paradigmei agricole naționale. Amfiteatru Economic, 20(47), pp.134-150.

European Commission, 2012. Survey programme for Classical Swine Fever (CSF). Unit G5 - Veterinary Programmes, [online] Available at: https://ec. europa.eu/food/sites/ food/files/safety/docs/cff_animal_vet-progs_2012_dec-2011-807-ec_classical-swinefever_rou.pdf, [Accessed 21 December 2018]. 
Fasina, F.O., Lazarus, D.D., Spencer, B.T., Makinde, A.A. and Bastos, A.D.S., 2012. Cost Implications of African Swine Fever in Smallholder Farrow-to-Finish Units: Economic Benefits of Disease Prevention Through Biosecurity. Transboundary and Emerging Diseases, [e-journal] 59(3), pp.244-255. Available through: Wiley Database https://onlinelibrary.wiley.com/doi/abs/10.1111/j.1865-1682.2011.01261.x

Grosu, V. and Socoliuc, M., 2008. New aspects of taxation system in agriculture. Bulletin UASVM, Horticulture, 65(2), pp.162-167.

Halasa, T., Bøtner, A., Mortensen, S., Christensen, H., Toft, N. and Boklund, A., 2016. Simulating the epidemiological and economic effects of an African swine fever epidemic in industrialized swine populations. Veterinary Microbiology, [e-journal] 193, pp.7-16. Available through: ScienceDirect database <http://www.sciencedirect.com/science/ article/pii/S03781135 16302097> [Accessed 9 December 2018].

Häsler, B., Howe, K.S. and Stärk, K.D.C., 2011. Conceptualising the technical relationship of animal disease surveillance to intervention and mitigation as a basis for economic analysis. BMC Health Services Research, [e-journal] 11(1), p.225. Available at: https://doi.org/10.1186/1472-6963-11-225.

Institutul National de Statistica, 2018. Efectivele de porcine existente la 1 mai, pe grupe de greutate si destinație economică. [online] Available at: <statistici.insse.ro:8077/tempoonline/\#/pages/tables/insse-table> [Accessed 14 December 2018].

Jurado, C., Martínez-Avilés, M., De La Torre, A., Štukelj, M., de Carvalho Ferreira, H.C., Cerioli, M., Sánchez-Vizcaíno, J.M. and Bellini, S., 2018. Relevant Measures to Prevent the Spread of African Swine Fever in the European Union Domestic Pig Sector. Frontiers in Veterinary Science, [online] 5, p. 77. Available at: <https://www.frontiersin.org/ article/10.3389/fvets.2018.00077> [Accessed 2 December 2018].

Rich, K.M. and Perry, B.D., 2011. The economic and poverty impacts of animal diseases in developing countries: New roles, new demands for economics and epidemiology. Preventive Veterinary Medicine, [online] 101(3), pp.133-147. Available through: ScienceDirect database <http://www.sciencedirect.com/science/article/pii/ S016758771000228X> [Accessed 11 December 2018].

Stanciu, S., 2014. The Romanian Swine Market in the EU Context. Annals of "Dunarea de Jos" University of Galati, Fascicle I. Economics and Applied Informatics, Years XX(3/2014), pp. 87-96.

Stanciu, S., 2015. Food of Animal Origin - Production and Safety Incidents in Romania. Saarbrücken, Germany: OmniScriptum GmbH \& Co. KG Publishing House.

Stanciu, S. and Sarbu, R., 2015, Resilience in the Romanian Food Industry. Preliminary Research. Annals of the University Dunarea de Jos of Galati: Fascicle: I, Economics \& Applied Informatics, 21(3), pp. 69-74.

Stanciu, S. and Sarbu, R., 2014. Economic Impact of Bluetongue Disease in Romanian Livestock Sector. In: IBIMA (International Business Information Management Association), 24th Conference: Crafting Global Competitive Economies: 2020 Vision Strategic Planning \& Smart Implementation. Milan, Italy, 6-7 November 2014. USA: IBIMA Publishing LLC.

Stanciu, S., Rizea, R.D. and Ilie, A.G., 2015. Study on the Competitiveness of the Romanian Meat Processing Industry. Amfiteatru Economic, 17 (Special No. 9), pp.1331-1345.

Topfirme.ro, 2018. Creșterea porcinelor, $\operatorname{Cod} C A E N$ 0146. [online] Available at: $<$ https://www.topfirme.com/> [Accessed 24 December 2018]. 